\title{
Excess nitrogen affects the frost sensitivity of the inner bark of Norway spruce
}

\author{
Anna Maria JÖNSSON*, Ulrika ROSENGREN, Bengt NIHLGÅRD \\ Department of Ecology, Plant Ecology and Systematics, Lund University, Ecology Building, 22362 Lund, Sweden
}

(Received 15 February 2002; accepted 16 June 2003)

\begin{abstract}
The sensitivity to frost in the living inner bark of trees have been hypothesised to be influenced by acid rain and $\mathrm{N}$ deposition through changes in nutrient balance and carbon metabolism. At the Skogaby experimental site, situated in southern Sweden, Norway spruce in control plots, plots fertilized with ammonium sulphate and plots fertilized with mineral nutrients except $\mathrm{N}$ were compared in this respect. Frost sensitivity was measured by electrolytic leakage and expressed as an index of injury. The results showed increased sensitivity to frost in the bark of trees treated with continuous applications of ammonium sulphate for 11 years. This was probably not only a direct effect of high nitrogen availability, but also caused by insufficient levels of other nutrients due to the rapid growth and changes in soil chemistry induced by the addition of ammonium sulphate. Mainly $\mathrm{Mg}$ and $\mathrm{K}$ seemed to be of importance for retaining a good frost resistance, supporting the hypothesis that nutrient imbalances increases the risk for development of frost related bark lesions in southern Sweden.
\end{abstract}

carbohydrates / index of injury / nutrient status / Picea abies / Skogaby / stem damage

Résumé - Effets d'un excès d'azote sur la sensibilité au froid de l'écorce interne de l'Epicéa. On a émis l'hypothèse selon laquelle la sensibilité au froid de la partie vivante interne de l'écorce des arbres serait influencée par les pluies acides et les dégâts azotés, par suite de changements de l'équilibre d'azote et du métabolisme du carbone. À la station expérimentale de Skogaby, située en Suède méridionale, on a comparé le comportement, sous cet angle, de l'épicéa dans un dispositif comportant des parcelles fertilisées avec divers nutrients à l'exclusion d'azote, ainsi que des parcelles témoins. La sensibilité au froid a été évaluée par des mesures de conductivité électrolitique, et exprimée par un indice de l'importance des dommages observés. Les résultats montrent une sensibilité accrue au froid de l'écorce des arbres traités d'une manière continue pendant 11 ans avec du sulfate d'ammoniac. Cela est probablement dû, non seulement à l'effet direct d'une importante disponibilité en azote, mais aussi à un niveau insuffisant de celle des autres nutrients, cela résultant d'une croissance plus rapide ainsi que de modifications des équilibres chimiques du sol induits par l'apport du sulfate d'ammoniac. Le rôle de $\mathrm{Mg}$ et $\mathrm{K}$ semble particulièrement important pour assurer une bonne résistance au froid, ce qui appuie l'hypothèse selon laquelle des déséquilibres entre nutrients augmentent le risque de lésions de l'écorce dans le sud de la Suède.

hydrates de carbone / indices de dommages / statut de nutrient / Picea abies / Skogaby / dégâts sur les tiges

\section{INTRODUCTION}

Frost damage results from temperatures decreasing lower than hardening status. They are usually caused by a rapid drop in temperature to below $0{ }^{\circ} \mathrm{C}$, following a warm period in the spring or autumn, or following a mild period at any time during the winter when the trees are not fully hardened. Spring frosts are therefor especially harmful when the trees have started to deharden [37, 40, 41]. It has been hypothesised that during the 1980's and 1990's the unusually mild winters in southern Sweden caused Norway spruce trees to deharden early, before the risk of frost damage had passed. The resulting damage was observed as bark necrosis and resin flow [4, 5]. Furthermore, until they had healed, these lesions remained susceptible to invasion by pathogenic insects and fungi, further increasing the damage and even killing the tree in severe cases [37].

High $\mathrm{N}$ deposition levels and acid rain can influence the trees' sensitivity to frost, as well as their sensitivity to other stress factors such as drought and pathogen attacks, via effects on the nutrient status [27]. Leaching of nutrients from needles and increased soil acidification which causes leaching of nutrients from the soil may contribute to nutrient imbalance in trees $[13,28]$. Increased growth, in response to increases in $\mathrm{N}$ availability, may induce deficiencies in other nutrients as a result of dilution effects [1]. These signs of nutrient imbalance have been observed in southern Sweden. Between 1985 and 1994, the K and Cu concentrations in Norway spruce needles decreased from more than sufficient to below optimum levels

\footnotetext{
* Corresponding author: Anna-Maria.Jonsson@ekol.lu.se
} 
[39]. The cause of this reduction in tree nutritional status is not clear but high $\mathrm{N}$ deposition and soil acidification in the area are considered to be the major factors [21]. To counteract nutrient deficiencies or imbalances in trees, vitality fertilization with ash and different types of mineral fertilizers can be carried out $[13,30]$.

Changes in nutrient status can influence frost hardiness by affecting carbon production, respiration and allocation, as well as via changes in membrane properties and osmotic potential [8]. Excess $\mathrm{N}$ in the tree may cause a shortage of carbohydrates, due to changes in carbon partitioning towards protein synthesis and arginine formation $[2,12]$. The maintenance respiration rates of needles are positively correlated to the concentration of $\mathrm{N}$ [36]. Hence enhanced $\mathrm{N}$ concentrations may increase respiration rates and thereby reduce non-structural carbohydrate reserves, including the sugars that are used for protection against frost during the winter [32]. Excess $\mathrm{N}$ may also cause buds to break earlier and delay the onset of dormancy, increasing the risk of damage caused by frost episodes in spring and autumn $[9,10]$. Adverse effects can also occur if the $\mathrm{N}$ concentration is unbalanced in relation to other nutrients, for instance $\mathrm{B}$, causing a relative nutrient deficiency [2].

Conifers with nutrient deficiencies are generally considered to have an increased sensitivity to frost, and fertilization with the deficient elements will increase the cold tolerance. However, contradictory results have been obtained, and this can be explained by differences among species, tissues and phenological states [8, 17, 22, 33]. Decreased sensitivity to frost has been observed in Sitka spruce needles with low concentrations of N, P or K [18] and Scots pine needles with a low concentration of K [19]. This may be due to a reduced growth rate causing increased concentrations of soluble carbohydrates and amino acids that act as cryoprotectants [26].

The aim of this study was to test the influence of needle and bark nutrient status in Norway spruce on the frost sensitivity of the bark. For this purpose we used the Skogaby field experimental site in southern Sweden. Here the nutrient status of trees has been altered artificially either by increasing $\mathrm{N}$ and $\mathrm{S}$ deposition or by adding a vitality fertilizer, i.e. $\mathrm{N}$-free fertilizer. We hypothesised that:

(a) trees fertilized with ammonium sulphate have an increased sensitivity to frost in the bark;

(b) the sensitivity to frost is related to nutrient deficiency and to an imbalance between $\mathrm{N}$ and other nutrients in the needles;

(c) the frost sensitivity is related to the concentrations of sugar and starch in the bark;

(d) the concentrations of sugar and starch in the bark are related to the nutrient status;

(e) effects of nutrient imbalance are more pronounced in large trees treated with ammonium sulphate, due to a higher ability to take up $\mathrm{N}$.

\section{MATERIALS AND METHODS}

\subsection{Field site}

The experimental area is situated in south-western Sweden (lat. 56 $33^{\prime}$, long. $13^{\circ} 13^{\prime}$ ) about $16 \mathrm{~km}$ from the coast and $95-115 \mathrm{~m}$ above sea level.
Table I. Nutrient contents $\left(\mathrm{kg} \cdot \mathrm{ha}^{-1}\right)$ in the vitality fertilizer "SkogVital" applied to Skogaby in 1988 and 1995.

\begin{tabular}{lcccccccc}
\hline Element $\left(\mathrm{kg} \cdot \mathrm{ha}^{-1}\right)$ & $\mathrm{P}$ & $\mathrm{K}$ & $\mathrm{Mg}$ & $\mathrm{Ca}$ & $\mathrm{S}$ & $\mathrm{B}$ & $\mathrm{Cu}$ & $\mathrm{Zn}$ \\
\hline Skogaby 1988 & 48 & 43 & 46 & 218 & 75 & 1.0 & - & 1.5 \\
Skogaby 1995 & 48 & 87 & 94 & 152 & 57 & 1.1 & 1.3 & 1.3 \\
\hline
\end{tabular}

The climate is maritime, with a mean annual precipitation of about $1100 \mathrm{~mm}$. May and June are often very dry and the annual mean air temperature is ca. $7.5^{\circ} \mathrm{C}$. The site was reforested with Norway spruce (Picea abies L. Karst.) of Polish origin (Istebna and Augustow) in 1966 after having been clear-cut to harvest a 50-year-old Scots pine stand. The mean $\mathrm{pH}$ of the precipitation is 4.5 (1988-1998) and the deposition in this area adds ca. $20 \mathrm{~kg} \cdot \mathrm{ha}^{-1} \cdot \mathrm{y}^{-1}$ of $\mathrm{N}$ and ca. $18 \mathrm{~kg} \cdot \mathrm{ha}^{-1} \cdot \mathrm{y}^{-1}$ of S via throughfall [6]. The soil is a Haplic podzol according to FAO (1988) [14], on loamy sand till, with a $\mathrm{pH}\left(\mathrm{H}_{2} \mathrm{O}\right)$ of ca. 3.9 in the humus layer and between 4.0 and 4.6 in the mineral soil layer down to a depth of $50 \mathrm{~cm} \mathrm{[7].} \mathrm{In} \mathrm{the} \mathrm{organic} \mathrm{layer,} \mathrm{the} \mathrm{C} / \mathrm{N}$ ratio was 25.7 and the base saturation approximately $30 \%$, whereas the base saturation in the mineral soil varied between $7 \%$ and $14 \%$ [7].

The experimental plots were established in 1987, and arranged in a randomised block design with four replicates. There were 2347 trees $^{-h^{-1}}$ at the start of the experiment, and $25 \%$ of the standing biomass was harvested during the winter of 1993-1994. For more details on the experimental design and site characteristics, see Bergholm et al. [7]. In this study, samples were taken from control plots, fertilized plots that were treated with $100 \mathrm{~kg} \cdot \mathrm{ha}^{-1}$ of $\mathrm{N}$ and $114 \mathrm{~kg} \cdot \mathrm{ha} \mathrm{a}^{-1}$ of $\mathrm{S}$ per year, spread as solid ammonium sulphate (NS) during 1988-1999, and vitality fertilized plots that were treated with $1000 \mathrm{~kg} \cdot \mathrm{ha}^{-1}$ of a commercial vitality fertilizer (manufactured by Hydro Agri, Sweden) added in 1988 and 1995 (Tab. I).

\subsection{Sampling of branches and needles}

Sampling was done in March 1999. In order to take into account possible effects due to differences in tree size, the trees with the smallest and the largest stem diameter along a $20 \mathrm{~m}$ long and $5 \mathrm{~m}$ wide transect at the easternmost side of each plot were sampled. Eight trees were sampled per treatment, 4 small and 4 large, in total 24 trees. The mean stem diameter was $24 \mathrm{~cm}$ for the large trees and $11 \mathrm{~cm}$ for the small trees. The standard deviation was $2 \mathrm{~cm}$ in both cases. Current year shoots were sampled from one branch pointing Southwest, at the 7 th branch whorl from the top, by climbing. All trees were equally exposed to the sun.

\subsection{Frost sensitivity test}

Bark samples were taken from the same trees as the shoot samples. Algae, lichens and the outer layer of dead bark were removed at breast height with a scraper on $100 \mathrm{~cm}^{2}$ of the southern side of the spruce stems. Thirteen samples of the inner live bark were taken from each tree with a hole punch, $1 \mathrm{~cm}$ in diameter. The samples were kept in capped plastic test tubes to prevent desiccation and were transported in a cool-box to the laboratory. Nine samples from each tree were placed in individual test tubes and stored at $+5{ }^{\circ} \mathrm{C}$ until late in the evening when the freezing treatments began.

The frost sensitivity test was performed according to Thomas and Blank [42]. Only two test temperatures, $-10^{\circ} \mathrm{C}$ and $-20^{\circ} \mathrm{C}$, were used, since the aim was to assess the relative difference in frost sensitivity among trees and not to measure the level of hardiness. Temperatures below $-20^{\circ} \mathrm{C}$ seldom occur in southern Sweden, and most frost damage occurs when the temperature drops rapidly below zero following a mild period. Three replicate bark samples from each tree were kept at 
Table II. Mean concentrations and standard deviations (sd) of nutrients in the needles of Norway spruce at Skogaby; a and b indicate significant effects of treatment on nutrient concentrations, $p<0.05$.

\begin{tabular}{lccccccccccc}
\hline Treatment & $\begin{array}{c}\mathrm{N} \\
\mathrm{mg} / \mathrm{g}\end{array}$ & $\begin{array}{c}\mathrm{P} \\
\mathrm{mg} / \mathrm{g}\end{array}$ & $\begin{array}{c}\mathrm{K} \\
\mathrm{mg} / \mathrm{g}\end{array}$ & $\begin{array}{c}\mathrm{Ca} \\
\mathrm{mg} / \mathrm{g}\end{array}$ & $\begin{array}{c}\mathrm{Mg} \\
\mathrm{mg} / \mathrm{g}\end{array}$ & $\begin{array}{c}\mathrm{S} \\
\mathrm{mg} / \mathrm{g}\end{array}$ & $\begin{array}{c}\mathrm{Mn} \\
\mathrm{mg} / \mathrm{g}\end{array}$ & $\begin{array}{c}\mathrm{Zn} \\
\mu \mathrm{g} / \mathrm{g}\end{array}$ & $\begin{array}{c}\mathrm{Cu} \\
\mu \mathrm{g} / \mathrm{g}\end{array}$ & $\begin{array}{c}\mathrm{B} \\
\mu \mathrm{g} / \mathrm{g}\end{array}$ \\
\hline Control & $12.6^{\mathrm{a}}$ & $1.27^{\mathrm{a}}$ & $5.30^{\mathrm{a}}$ & $1.95^{\mathrm{ab}}$ & $0.90^{\mathrm{a}}$ & $0.81^{\mathrm{a}}$ & $0.91^{\mathrm{a}}$ & $21.50^{\mathrm{ab}}$ & $2.63^{\mathrm{a}}$ & $26.95^{\mathrm{a}}$ \\
& $(1.41)$ & $(0.18)$ & $(1.25)$ & $(0.50)$ & $(0.15)$ & $(0.078)$ & $(0.50)$ & $(8.80)$ & $(0.34)$ & $(4.66)$ \\
Ammonium sulphate & $19.06^{\mathrm{b}}$ & $1.17^{\mathrm{a}}$ & $4.27^{\mathrm{a}}$ & $1.06^{\mathrm{b}}$ & $0.55^{\mathrm{b}}$ & $0.92^{\mathrm{a}}$ & $0.47^{\mathrm{a}}$ & $10.72^{\mathrm{a}}$ & $2.52^{\mathrm{a}}$ & $19.44^{\mathrm{b}}$ \\
& $(2.20)$ & $(0.13)$ & $(1.31)$ & $(0.58)$ & $(0.12)$ & $(0.09)$ & $(0.18)$ & $(3.78)$ & $(0.43)$ & $(4.32)$ \\
Vitality fertilizer & $13.24^{\mathrm{a}}$ & $1.76^{\mathrm{b}}$ & $6.09^{\mathrm{a}}$ & $2.63^{\mathrm{a}}$ & $1.01^{\mathrm{a}}$ & $0.92^{\mathrm{a}}$ & $0.63^{\mathrm{a}}$ & $32.67^{\mathrm{b}}$ & $2.72^{\mathrm{a}}$ & $25.38^{\mathrm{ab}}$ \\
& $(1.63)$ & $(0.32)$ & $(1.67)$ & $(1.02)$ & $(0.25)$ & $(0.16)$ & $(0.22)$ & $(12.44)$ & $(0.91)$ & $(7.23)$ \\
\hline
\end{tabular}

Table III. Mean concentrations and standard deviations (sd) of elements in the inner bark of Norway spruce at Skogaby; a and b indicate significant effects of treatment on element concentrations, $p<0.05$.

\begin{tabular}{lccccccccccc}
\hline Treatment & $\begin{array}{c}\mathrm{P} \\
\mathrm{mg} / \mathrm{g}\end{array}$ & $\begin{array}{c}\mathrm{K} \\
\mathrm{mg} / \mathrm{g}\end{array}$ & $\begin{array}{c}\mathrm{Ca} \\
\mathrm{mg} / \mathrm{g}\end{array}$ & $\begin{array}{c}\mathrm{Mg} \\
\mathrm{mg} / \mathrm{g}\end{array}$ & $\begin{array}{c}\mathrm{S} \\
\mathrm{mg} / \mathrm{g}\end{array}$ & $\begin{array}{c}\mathrm{Mn} \\
\mathrm{mg} / \mathrm{g}\end{array}$ & $\begin{array}{c}\mathrm{Zn} \\
\mathrm{mg} / \mathrm{g}\end{array}$ & $\begin{array}{c}\mathrm{Cu} \\
\mu \mathrm{g} / \mathrm{g}\end{array}$ & $\begin{array}{c}\mathrm{B} \\
\mu \mathrm{g} / \mathrm{g}\end{array}$ & $\begin{array}{c}\mathrm{Fe} \\
\mu \mathrm{g} / \mathrm{g}\end{array}$ & $\begin{array}{c}\mathrm{Al} \\
\mu \mathrm{g} / \mathrm{g}\end{array}$ \\
\hline Control & $0.56^{\mathrm{a}}$ & $3.42^{\mathrm{ab}}$ & $6.38^{\mathrm{a}}$ & $0.84^{\mathrm{a}}$ & $0.39^{\mathrm{a}}$ & $1.35^{\mathrm{a}}$ & $0.19^{\mathrm{a}}$ & $3.25^{\mathrm{a}}$ & $12.50^{\mathrm{a}}$ & $19.74^{\mathrm{a}}$ & $115.17^{\mathrm{a}}$ \\
& $(0.13)$ & $(1.22)$ & $(2.02)$ & $(0.19)$ & $(0.10)$ & $(0.65)$ & $(0.049)$ & $(1.22)$ & $(4.40)$ & $(12.17)$ & $(81.66)$ \\
Ammonium & $0.58^{\mathrm{a}}$ & $3.14^{\mathrm{a}}$ & $5.85^{\mathrm{a}}$ & $0.87^{\mathrm{a}}$ & $0.51^{\mathrm{a}}$ & $1.12^{\mathrm{a}}$ & $0.17^{\mathrm{a}}$ & $3.09^{\mathrm{a}}$ & $16.24^{\mathrm{a}}$ & $13.45^{\mathrm{a}}$ & $153.81^{\mathrm{a}}$ \\
Sulphate & $(0.17)$ & $(0.91)$ & $(1.17)$ & $(0.21)$ & $(0.16)$ & $(0.26)$ & $(0.05)$ & $(0.70)$ & $(10.40)$ & $(7.41)$ & $(83.61)$ \\
Vitality fertilizer & $0.74^{\mathrm{b}}$ & $4.59^{\mathrm{b}}$ & $7.21^{\mathrm{a}}$ & $1.06^{\mathrm{a}}$ & $0.39^{\mathrm{a}}$ & $0.83^{\mathrm{a}}$ & $0.19^{\mathrm{a}}$ & $3.30^{\mathrm{a}}$ & $13.42^{\mathrm{a}}$ & $22.30^{\mathrm{a}}$ & $119.84^{\mathrm{a}}$ \\
& $(0.13)$ & $(1.10)$ & $(1.02)$ & $(0.15)$ & $(0.04)$ & $(0.46)$ & $(0.02)$ & $(0.60)$ & $(4.48)$ & $(17.56)$ & $(40.54)$ \\
\hline
\end{tabular}

$+5{ }^{\circ} \mathrm{C}$ as a control. Three bark samples were frozen during $30 \mathrm{~min}$ in a freezing cabinet, ProfiMaster National Lab, holding the test temperature. The bark samples were acclimatised at $+5^{\circ} \mathrm{C}$ for $10 \mathrm{~h}$ before freezing, and thawed at $+5{ }^{\circ} \mathrm{C}$ for $10 \mathrm{~h}$ in order to avoid extreme temperature gradients, i.e. room temperature, which would have exacerbated the damage. When thawed, $5 \mathrm{~mL}$ of $3 \%$ propanol was added to all the bark samples. They were then incubated in darkness for $24 \mathrm{~h}$ at $25^{\circ} \mathrm{C}$. During that time ions from the bark tissue leaked into the propanol solution, the greater the injury, the more leaked ions. Conductivity was measured with a CDM92 conductivity meter (Radiometer, Copenhagen) with a reference temperature of $20^{\circ} \mathrm{C}$. All samples were then autoclaved for $20 \mathrm{~min}$ at $120^{\circ} \mathrm{C}$ and reincubated in darkness for $24 \mathrm{~h}$ at $25^{\circ} \mathrm{C}$, after which the conductivity was measured. An index of injury ranging from $0=$ no freezing damage to $100=$ completely killed by freezing treatment was calculated: $\mathrm{I}_{\mathrm{t}} \mathrm{x}=100 \times(\mathrm{RCfrozen}-\mathrm{RC}$ control $) /$ ( 1 - RCcontrol), where $\mathrm{x}$ is the test temperature, $-10^{\circ} \mathrm{C}$ or $-20^{\circ} \mathrm{C}$, and $\mathrm{RC}$ is the relative conductivity calculated as conductivity before autoclaving divided by conductivity after autoclaving.

\subsection{Analysis of element concentrations in needles and bark}

The shoots were dried at $40{ }^{\circ} \mathrm{C}$, until the needles fell off. The concentration of $\mathrm{N}$ in the needles was analysed using the Kjeldahl-method, with $\mathrm{K}_{2} \mathrm{SO}_{4}$ and $\mathrm{CuSO}_{4}$ (1:10 by weight) as catalysts. Inductively Coupled Plasma spectrometry (ICP) analysis was carried out for Al, $\mathrm{B}, \mathrm{Ca}, \mathrm{Cu}, \mathrm{Fe}, \mathrm{K}, \mathrm{Mg}, \mathrm{Mn}, \mathrm{P}, \mathrm{S}$ and $\mathrm{Zn}$ on needles and bark. A sample of $1000 \mathrm{mg}$ needles and two pieces of bark, respectively, was digested in $20 \mathrm{~mL}$ of concentrated $\mathrm{HNO}_{3}$ and heated to $125^{\circ} \mathrm{C}$ before ICP analysis. The concentration of $\mathrm{Fe}$ in the needles was not considered since most was assumed to be from soil dust deposition $[7,43]$. The optimum levels for mean ratios of mineral nutrients to nitrogen $(\%)$ in the current year needles were set according to Linder [25].

\subsection{Sugar and starch analysis}

Two pieces of bark from each tree were freeze-dried and ground into fine powder in a ballmill. The powder was put into percolators. The sugars were extracted with $80 \%$ ethanol and the starch was extracted with $35 \%$ perchloric acid from $25 \mathrm{mg}$ of the bark samples according to Hansen and Möller [16].

\subsection{Statistics}

The dataset was analyzed using ANOVA. Treatment and size-class were treated as fixed effects and block as a random effect. Interactions between treatment and size-class were analysed. The Tukey Kramer post hoc test was used for evaluating treatment effects. The ANOVA assumptions were tested for all variables, and no transformation was required. Regression analyses and stepwise multiple regression with forward selection of variables were used for studying the relations between frost sensitivity, concentrations of mineral nutrients and carbohydrates. All statistical analysis was done according to Sokal and Rohlf [38] using Systat 5.2.1 for Macintosh. Standard deviation was indicated by \pm .

\section{RESULTS}

In the plots treated with ammonium sulphate (Tabs. II and III) the foliar $\mathrm{N}$ concentration was significantly higher, while concentrations of $\mathrm{Ca}, \mathrm{Mg}, \mathrm{Zn}$ and $\mathrm{B}$ were lower than in the control and vitality fertilized plots. The needle concentrations of $\mathrm{P}$ and $\mathrm{Zn}$, and the bark concentrations of $\mathrm{P}$ and $\mathrm{K}$ (Tab. III and Fig. 3) were significantly greater in the vitality fertilized plots. The $\mathrm{K} / \mathrm{N}$, $\mathrm{P} / \mathrm{N}$ and $\mathrm{Mg} / \mathrm{N}$ ratios were below the level considered necessary 

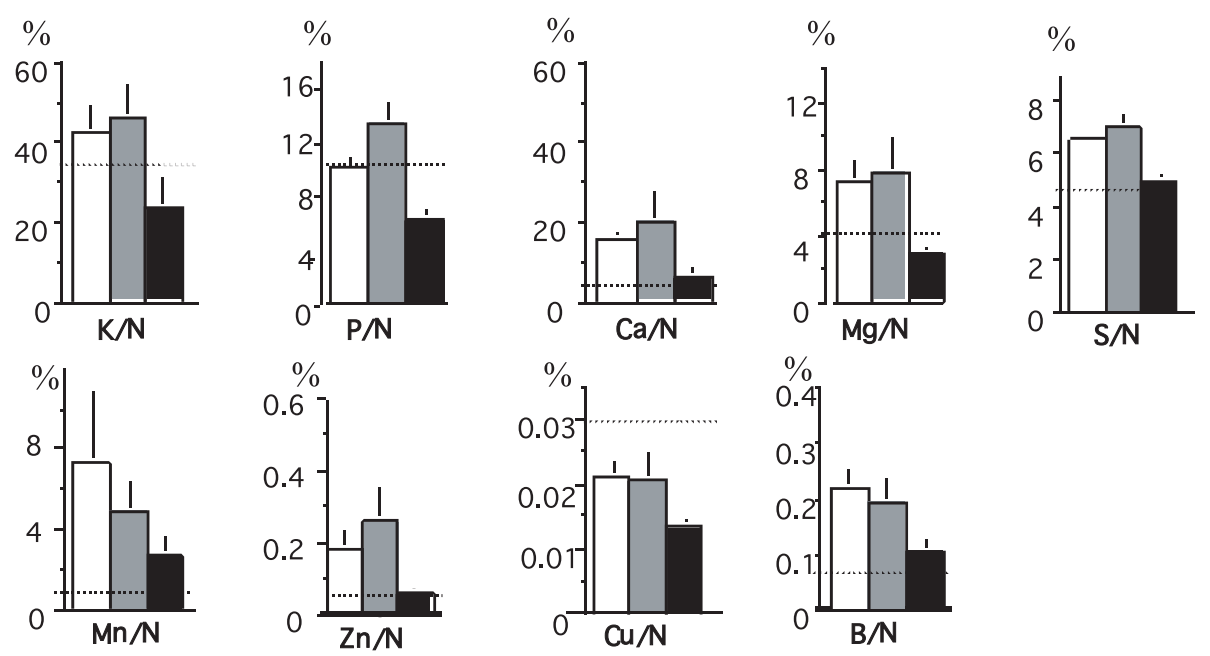

Figure 1. Mean ratios of mineral nutrients to nitrogen (\%) in the current year needles of Norway spruce subjected to different treatments at Skogaby. Standard deviations are indicated by a line on top of the bars. Dotted lines indicate optimum level according to Linder (1995). $\square=$ control; $\mathbf{\square}=$ vitality fertilizer; $\boldsymbol{\square}=$ ammonium sulphate .

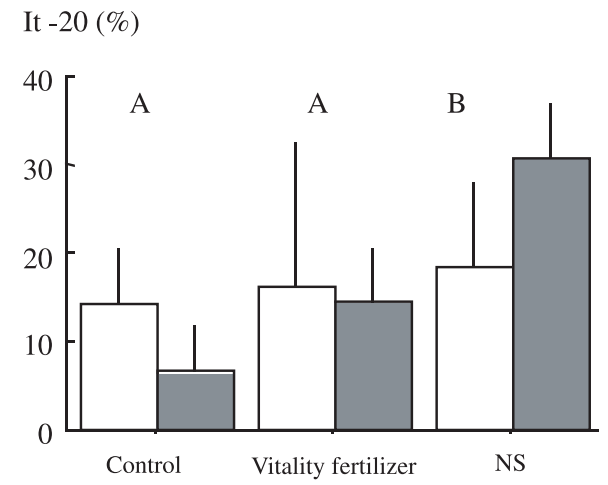

Figure 2. Frost sensitivity, measured as an index of injury at $-20{ }^{\circ} \mathrm{C}$, for Norway spruce in control plots and plots treated with a vitality fertilizer or plots treated with ammonium sulphate (NS). Trees with a small diameter were compared to trees with a large diameter. The lines on top of the bars indicate standard deviations. Bars with different letters denote significant differences between treatments $(p \leq$ 0.05). $\square=$ small trees; $\square=$ large trees.

for optimal growth in the trees treated with ammonium sulphate, whereas the $\mathrm{Cu} / \mathrm{N}$ ratio was below optimum in all plots (Fig. 1).

The bark was more damaged at $-20{ }^{\circ} \mathrm{C}$ (on average $16.8 \% \pm$ $10.9)$ than at $-10{ }^{\circ} \mathrm{C}($ on average $5.3 \% \pm 5.9)(p<0.0001)$. The index of injury at $-10^{\circ} \mathrm{C}$ did not differ among treatments. The trees treated with ammonium sulphate were more sensitive at $-20{ }^{\circ} \mathrm{C}$ than trees from control and vitality fertilized plots $(p=0.02)$ (Fig. 2).

There was a significant positive correlation between the frost sensitivity at $-20{ }^{\circ} \mathrm{C}$ and the concentration of $\mathrm{N}$ in needles $\left(p=0.02, r^{2}=0.38\right)$. Stepwise multiple regression analysis did not include $\mathrm{N}$, but the concentration of $\mathrm{K}$ in bark and needles, $\mathrm{B}$ and $\mathrm{Ca}$ in needles and $\mathrm{Mn}$ in bark $\left(p=0.002, r^{2}=0.67\right)$.
Thus, the highest correlation was found with a combination of mineral nutrients in bark and needles. Trees with a $\mathrm{Mg} / \mathrm{N}$ ratio below the level for optimal growth were significantly more frost sensitive at $-20{ }^{\circ} \mathrm{C}(p=0.01)$.

The concentrations of sugar (on average $144 \mathrm{mg} \cdot \mathrm{g}^{-1} \pm 24$ ) and starch (on average $55 \mathrm{mg} \cdot \mathrm{g}^{-1} \pm 14 \mathrm{mg} \cdot \mathrm{g}^{-1}$ ) did not differ among treatments and were not correlated to the indices of injury. According to multiple regression analysis, the concentration of sugar was related to the concentrations of $\mathrm{K}$ and $\mathrm{P}$ in needles $\left(p=0.03, r^{2}=0.31\right)$, and the concentration of starch was related to the concentrations of $\mathrm{K}$ in needles, $\mathrm{Zn}$ and $\mathrm{Na}$ in the bark $\left(p=0.008, r^{2}=0.48\right)$.

There were no significant differences in frost sensitivity between small and large trees for any treatment or temperature, but large trees treated with ammonium sulphate tended to be the most frost sensitive (Fig. 2). Large trees had higher concentrations of $\mathrm{K}(p=0.03)$ and sugar $(p=0.04)$ in the bark than small trees (Fig. 3).

\section{DISCUSSION}

The effects of the different fertilizer regimes on tree nutrient status were consistent with earlier findings from the Skogaby site $[30,35]$. The nutrient imbalance in trees treated with ammonium sulphate developed gradually over the years since the start of the treatment, and can be explained by a dilution effect caused by increased growth, increased soil acidification and decreased base saturation in the soil [31]. During the first three years of the treatment, trees fertilised with ammonium sulphate grew approximately $25 \%$ more than those in the control plots [29]. However, after a few years of relatively high growth, the growth rate decreased to equal that of the control trees in 1996, and from 1997 onward fell below that of the control trees [34], showing the nutrient impact on tree metabolism. Increased concentrations of $\mathrm{P}, \mathrm{K}, \mathrm{Ca}, \mathrm{Mg}$ and $\mathrm{B}$ in the needles have been measured in the trees treated with the vitality fertilizer 

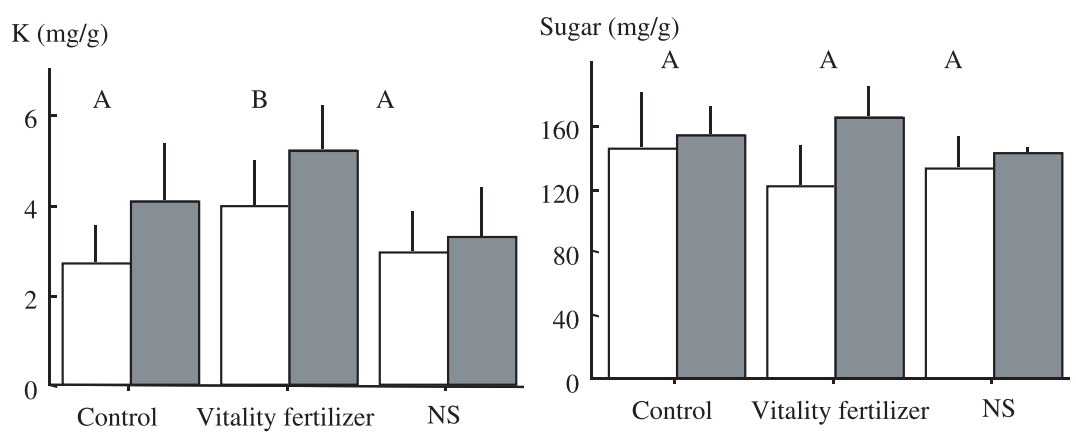

Figure 3. The concentrations of $\mathrm{K}$ and sugar in the bark of Norway spruce in control plots and plots treated with a vitality fertilizer or plots treated with ammonium sulphate (NS). Trees with a small diameter were compared to trees with a large diameter. Bars with different letters denote significant differences between treatments $(p \leq 0.05)$. The lines on top of the bars indicate standard deviations. $\square=$ small trees; $\square=$ large trees.

[30]. In this study, only increased concentrations of $\mathrm{P}$ and $\mathrm{Zn}$ were detected.

The frost damage caused at $-10{ }^{\circ} \mathrm{C}$ was too slight, only a few percent, to detect either differences among treatments or any influence of nutrient status. By contrast, the effects at $-20^{\circ} \mathrm{C}$ clearly indicated the negative influence of the addition of ammonium sulphate. The correlation between frost sensitivity and $\mathrm{N}$ concentration in the needles suggested an effect of imbalance between $\mathrm{N}$ and other nutrients, and this was detected as a higher frost sensitivity in trees with a lower than optimal $\mathrm{Mg} / \mathrm{N}$ ratio. The concentrations of $\mathrm{K}$ in bark was selected by the stepwise multiple regression analysis as the variable with the highest explanatory value. This may, however, not imply a causal relationship as experiments on conifer seedlings have found that $\mathrm{K}$ does not affect the level of hardiness [11, 24]. The concentration of $\mathrm{K}$ has a large impact on the transpiration [23], and this may affect the frost sensitivity indirectly.

The concentrations of sugar and starch were related to the concentration of $\mathrm{K}$ in needles in combination with other nutrients. Although the trees treated with ammonium sulphate had a concentration of $\mathrm{N}$ above $15 \mathrm{mg} / \mathrm{g}$, indicating an accumulation of arginin [6], there was no relation between $\mathrm{N}$ and carbohydrates. Nor was there any correlation between the concentration of carbohydrates and the frost sensitivity. The concentrations of different sugars may be more relevant than the total sum, as frost resistance in Norway spruce seedlings has been found to be strongly correlated with the accumulation of sucrose and raffinose [3].

In general, larger trees have a larger leaf area and thus transpire more than small trees. This causes a relatively larger uptake of ions with high diffusion coefficients in the soil, such as $\mathrm{NO}_{3}{ }^{-}$ and $\mathrm{K}^{+}$, which follow the mass flow of water [15]. This could be the reason for higher concentrations of $\mathrm{K}$ in large trees, and may have contributed to the higher concentration of sugar. However, the large trees were hypothesised to encounter a nutrient imbalance earlier than small trees. This was not evident in this study, although there was a tendency for the large trees treated with ammonium sulphate to be the most frost sensitive.

It was difficult to assess the impact of a specific nutrient in this field experiment since the treatments have affected several nutrients at the same time. Also, a correlation to nutrient concentrations and ratios can only be expected if there is a diffe- rence between the trees studied [20]. For instance, the $\mathrm{Cu} / \mathrm{N}$ ratio was below the level considered optimal in all treatments, hence all trees were affected approximately equally and a potential influence on frost sensitivity and carbohydrate concentrations is then less likely to be detected. In another study on 30-40 year-old Norway spruce in southern Sweden, the frost sensitivity of the bark and hardiness status of needles were related to the concentrations of $\mathrm{P}$ and $\mathrm{Mg}$ in bark and needles, which in turn was related to differences in soil fertility between the study sites. The results also indicated influence of K [20]. Both this and the present study support the hypothesis that nutrient imbalances increases the risk for development of frost related bark lesions in southern Sweden.

\section{CONCLUSIONS}

- Continuous applications of ammonium sulphate for 11 years increased the frost sensitivity of Norway spruce bark.

- Although difficult to assess the impact of a specific nutrient, mainly $\mathrm{Mg}$ and $\mathrm{K}$ seemed to be of importance for retaining a good frost resistance. Low levels of these nutrients were probably caused by accelerated growth rates and growth dilution. Soil acidification and ion leakage associated with the ammonium sulphate fertilization further decreased their availability.

- The frost sensitivity was not related to the concentrations of sugar and starch in the bark, although the concentrations of sugar and starch in the bark were related to the tree nutrient status.

- Nutrient imbalance was not aggravated in large trees growing in plots treated with ammonium sulphate.

Acknowledgements: We are grateful to Anders Jonshagen for sampling the needles, to Ragnhild Ohlin, Siv Billberg, Irené Persson, Maj-Lis Gernersson and Tommy Olsson for help with the analysis, to Dr. Lucy Sheppard and two anonymous reviewers for valuable comments on the manuscript, and to Abigail Sykes for revising the language. We would like to thank the Skogaby project for allowing us to take the samples. This study was financially supported by SUFOR, the Swedish Mistra foundation.

\section{REFERENCES}

[1] Aronsson A., Frost hardiness in Scots pine (Pinus silvestris L.), Stud. For. Suec. 155 (1980) 1-27. 
[2] Aronsson A., Indications of stress at unbalanced nutrient contents of spruce and pine, K. Skogs- o. Lantbr. akad. tidskr. Suppl. 17 (1985) 40-51.

[3] Aronsson A., Ingestad T., Lööf L.-G., Carbohydrate metabolism and frost hardiness in pine and spruce seedlings grown at different photoperiods and thermoperiods, Physiol. Plant. 36 (1976) 127-132.

[4] Barklund P., Wahlström K., Bark necrosis and resin bleeding in Norway spruce in Sweden, in: Disease/Environment interactions in forest decline, Proceedings of a workshop of the IUFRO working party 7. 02. 06, Vienna, Austria, March 16-21, 1998.

[5] Barklund P., Ericsson A., Gemmel P., Johansson U., Olsson M., Walheim M., Åhman G., Bark och vedskador hos granar med kådflöde - kådflödessjukan hos gran. SLU Info/Skog. Rapport 15, Alnarp, ISBN 91-576-4958-8, 1995 (in Swedish).

[6] Bergholm J., Berggren D., Hur försurades marken? Studier av deposition, mark och markvatten, in: Persson T., Nilsson L.-O. (Eds.), Skogabyförsöket - effekter av långvarig kväve- och svaveltillförsel till ett skogsekosystem (The Skogaby experiment - effects of N and S deposition to a forest ecosystem), SNV report 5173, 2001 (in Swedish).

[7] Bergholm J., Jansson P.-E., Johansson U., Majdi H., Nilsson L.-O., Persson H., Rosengren-Brinck U., Wiklund K., Air pollution, tree vitality and forest production - the Skogaby project. General description of a field experiment with Norway spruce in southern Sweden, in: Nilsson L.-O., Hüttl R.F. (Eds.), Nutrient uptake and cycling in forest ecosystems, CEC/IUFRO-symposium in Halmstad June 7-10 1993, Ecosystem report No. 13, EUR 15465, ISBN 92-826-6468-6, 1995.

[8] Bigras F.J., Ryyppö A., Lindström A., Stattin E., Cold acclimation and deacclimation of shoots and roots of conifer seedlings, in: Bigras F.J., Colombo S.J. (Eds.), Conifer cold hardiness, Kluwer Academic Publishers, Dordrecht, The Netherlands, 2001.

[9] Burke M.K., Raynal D.J., Mitchell M.J., Soil nitrogen availability influences seasonal carbon allocation patterns in sugar maple (Acer saccharum), Can. J. For. Res. 22 (1992) 447-456.

[10] Cannell M.G.R., Sheppard L.J., Seasonal changes in the frost hardiness of provenances of Picea sitchensis in Scotland, Forestry 55 (1982) 137-153.

[11] Christersson L., The effect of inorganic nutrients on water economy and hardiness of conifers. Part 1 . The effect of varying potassium, calcium and magnesium levels on water content, transpiration rate and the initial phase of development of frost hardiness of Pinus sylvestris seedlings, Stud. For. Suec. 103 (1973) 1-26.

[12] Dueck T.A., Dorèl F.G., Horst R.T., Van der Eerden L.J., Effects of ammonia, ammonium sulphate and sulphur dioxide on the frost sensitivity of Scots pine (Pinus sylvestris L.), Water Air Soil Pollut. 54 (1990/91) 35-49.

[13] Evers F.H., Hüttl R.F., A new fertilization strategy in declining forests, Water Air Soil Pollut. 54 (1990/91) 495-508.

[14] FAO-UNESCO, Soil map of the world. Revised legend, FAO, Rome, 1988.

[15] Fitter A.H., Hay R.K.M., Environmental physiology of plants, 2nd ed., Academic Press, London, 1989.

[16] Hansen J., Möller I., Percolation of starch and soluble carbohydrates from plant tissue for quantitative determination with anthrone, Analyt. Biochem. 68 (1975) 87-94.

[17] Hansen J.M., Effects of nutritional factors on frost hardening in Larix leptolepis (Sieb \& Zucc.) Gord., Scand. J. For. Res. 7 (1992) 183-192.

[18] Jalkanen R.E., Redfern D.B., Sheppard L.J., Nutrient deficits increase frost hardiness in Sitka spruce (Picea sitchensis) needles, For. Ecol. Manage. 107 (1998)191-201.

[19] Jokela A., Sarjala T., Huttunen S., The structure and hardening status of Scots pine needles at different potassium availability levels, Trees 12 (1998) 490-498.

[20] Jönsson A.M., Kivimäenpää M., Stjernquist I., Sutinen S., Frost hardiness in bark and needles of Norway spruce in southern Sweden, Trees 15 (2001) 171-176.
[21] Jönsson U., Rosengren U., Thelin G., Nihlgård B., Acidification induced chemical changes in coniferous forest soils in southern Sweden, Environ. Pollut. 123 (2003) 75-83.

[22] Klein R.M., Perkins T.D., Myers H.L., Nutrient status and winter hardiness of red spruce foliage, Can. J. For. Res. 19 (1989) 754-758.

[23] Larsen J.B., Drought resistance, water relations and growth of Douglas fir and Grand fir in relation to nutrient supply, Det forstlige forsøgsvæsen i Danmark bd 39 (1983) 1-82.

[24] Larsen J.B., Muhle O., Lohbeck H., Untersuchungen zur Bestandesbegründung der Douglasie, Schriften aus der Forstlichen Fakultät der Universität Göttingen und der Niedersächsischen Forstlichen versuchsanstalt, Band 52, J.D. Sauerländer's Verlag, Frankfurt am Main, 1978

[25] Linder S., Foliar analysis for detecting and correcting nutrient imbalances in Norway spruce, Ecol. Bull. 44 (1995) 178-190.

[26] Marschner H., Mineral nutrition of higher plants, 2nd ed., Academic press, London, 1995.

[27] Nihlgård B., The ammonium hypothesis - an additional explanation to the forest dieback in Europe, Ambio 14 (1985) 2-8.

[28] Nihlgård B., Forest decline and environmental stress, in: Brune D., Chapman D.V., Gwynne M.D., Pacyna J.M. (Eds.), The global environment; science, technology and management, Scandinavian Science, Oslo, 1997.

[29] Nilsson L.-O., Wiklund K., Influence of nutrient and water stress on Norway spruce production in south Sweden - the role of air pollutants, Plant Soil 147 (1992) 251-265.

[30] Nilsson L.-O., Wiklund K., Nutrient balance and P, K, Ca, Mg, S and $\mathrm{B}$ accumulation in a Norway spruce stand following ammonium sulphate application, fertigation, irrigation, drought and $\mathrm{N}$-free-fertilisation, Plant Soil 168-169 (1995) 437-446.

[31] Nilsson, L.-O., Wiklund K., Indirect effects of N and S deposition on a Norway spruce ecosystem. An update of findings within the Skogaby project, Water Air Soil Pollut. 85 (1995) 1613-1622.

[32] Ögren E., Nilsson T., Sundblad L.-G., Relationship between respiratory depletion of sugars and loss of cold hardiness in coniferous seedlings over-wintering at raised temperatures: indications of different sensitivities of spruce and pine, Plant. Cell Environ. 20 (1997) 247-253.

[33] Pellett H.M., Carter J.V., Effect of nutritional factors on cold hardiness of plants, Hortic. Rev. 3 (1981) 144-171.

[34] Persson T., Nilsson L.-O. (Eds.), Skogabyförsöket - effekter av långvarig kväve- och svaveltillförsel till ett skogsekosystem (The Skogaby experiment - effects of $\mathrm{N}$ and $\mathrm{S}$ deposition to a forest ecosystem), SNV report 5173, 2001 (in Swedish).

[35] Rosengren-Brinck U., Nihlgård B., Nutritional status in needles of Norway spruce (Picea abies) in relation to water and nutrient supply, Ecol. Bull. 44 (1995) 168-177.

[36] Ryan M.G., Effects of climate change on plant respiration, Ecological Applications 1 (1991) 157-167.

[37] Schoeneweiss D.F., Predisposition, stress and plant disease, in: Annu. Rev. Phytopathol. Vol. 13, 1975, 412 p.

[38] Sokal R.R., Rohlf F.J., Biometry, 3rd ed., Freeman and Company, New York, 1995.

[39] Thelin G., Rosengren-Brinck U., Nihlgård B., Barkman A., Trends in needle and soil chemistry of Norway spruce and Scots pine stands in southern Sweden 1985-1994, Environ. Pollut. 99 (1998) 149-158.

[40] Thomas F.M., Hartmann G., Frosthärte des Bastes älterer Traubeneichen auf besonnten und absonnigen Stammseiten, Forst und Holz 47 (1992) 462-464.

[41] Thomas F.M., Büttner G., Excess nitrogen, drought and winter frost as possible predisposing factors of oak decline in northern Germany, in: Luisi N., Lerario P., Vannini A. (Eds.), Recent advances in studies on oak decline, Proceedings of an international congress, ISBN 88-86337-00-0, 1993.

[42] Thomas F.M., Blank R., The effect of excess nitrogen and of insect defoliation on the frost hardiness of bark tissue of adult oaks, Ann. Sci. For. 53 (1996) 395-406.

[43] Wyttenbach A., Tobler L., Bajo S., Nadelinhaltstoffe und Ablagerungen auf Nadeloberflächen von Fichten (Picea abies Karst.), Forstw. Cbl. 108 (1989) 233-243. 